\title{
UMA REVISÃO DA ESTÉTICA NEGRA DOS BLOCOS AFRO DE CARNAVAL BAHIANO ILÊ AIYÊ, OLODUM, MALÊ DEBALÊ E BANKOMA
}

\author{
UNA REVISÓN DE LA ESTÉTICA NEGRA EN EL GRUPOS \\ DE CARNAVAL AFRO BAHIANO DE ILÊ AIYÊ, OLODUM, \\ MALE DEBALE Y BANKOMA
}

\section{A REVIEW OF BLACK AESTHETICS IN THE BAHIAN AFRO CARNIVAL GOUPS ILÊ AIYÊ, OLODUM, MALÊ DEBALÊ AND BANKOMA}

\author{
Nadir Nóbrega Oliveira ${ }^{1}$
}

\begin{abstract}
RESUMO
Neste artigo eu faço uso de várias referências envolvendo corpo, dança, ancestralidade e memória nos blocos afro baianos: Ilê Aiyê, Olodum, Malê Debalê e Bankoma, destacando aspectos das culturas e identidades brasileira nestas criações. Não se pode desconsideraras grandes contribuições destes blocos afro de carnaval em várias questões, cuja herança é bastante significativa para os campos da dança, das artes cênicas, da música entre outros.

PALAVRAS-CHAVE: Dança, Corpo, Estética negra

\section{RESUMEN}

En este artículo utilizo varias referencias que involucran cuerpo, danza, ascendencia y memoria en los bloques afro salvadoreños: Ilê Aiyê, Olodum, Malê Debalê y Bankoma, destacando aspectos de las culturas e identidades brasileñas en estas creaciones. No se pueden ignorar las grandes contribuciones de estos grupos de carnaval afro en varios temas, cuya herencia es bastante significativa para los campos de la danza, las artes escénicas, la música, entre otros.
\end{abstract}

PALABRAS CLAVE: Danza, Cuerpo, Estética negra

\begin{abstract}
In this article I make use of several references involving body, dance, ancestry and memory in the Bahian Afro groups: Ilê Aiyê, Olodum, Malê Debalê and Bankoma, highlighting aspects of Brazilian cultures and identities in these creations. One cannot disregard the great contributions of these Afro carnival groups on various issues, whose inheritance is quite significant for the fields of dance, performing arts, music, among others.
\end{abstract}

KEYWORDS: Dance, Body, Black aesthetic

\footnotetext{
1 Pós-Doutora em Artes Cênicas do PPGAC/UFBA. Licenciada em Dança pela UFBA. Coreógrafa, dançarina e escritora. Professora aposentada Adjunta da Universidade Federal de Alagoas.
} 
Você pode até achar que impressiona

Aqui no Ilê Aiyê a preferência é ser chamada de negona

(Mário Pam)

Inicio aqui esse artigo com essa epígrafe da música Alienação do bloco afro carnavalesco Ilê Aiyê. O Brasil mudou a "sua cara", a partir dos anos 1970, pois foi nessa época que se iniciaram decisões políticas e culturais para negros, indígenas e brancos, nas questões referentes a gênero, raça e classe, redefinindo, assim, a sociedade brasileira. Muito dessas lutas foi imposto pelo Movimento Negro e organizado a partir da obrigatoriedade da aplicação da Lei Federal de $n^{0}$. 11.645/ 2008. O termo "negro" ainda é criticado por muitos, argumentando que esta palavra inferioriza as pessoas que possuem tons de pele escura, preferindo intitulálas de "moreninha", "escurinha", "jambete", "roxinha", "morena escura" e até mesmo "mulata2".

Ainda é difícil para alguns, aceitarem-se como negro na sociedade, essa palavra representa o sinônimo de "pobre" e de "escravizado". Os blocos afro e outros compositores brasileiros utilizam este termo étnico, nas suas canções, para reivindicar um passado ancestral e as desigualdades que refletem no psicológico, podendo se resumir nesta canção da sambista carioca Dona Ivone Lara "Sorriso Negro" (1982) que diz assim: "Um sorriso negro/ um abraço negro/ Traz felicidade/ Nêgo sem emprego fica sem sossego/Negro é a raiz da liberdade".

Estas histórias orais que constituíram as tessituras deste artigo, estão associadas a minha história de vida no bairro do Uruguai, em Salvador, no convívio do meu lar, constituído pelos meus avós maternos Edelvira e Manoel. Acredito que, desde criança, já tinha sensibilidade para a arte estimulada pelos meus familiares. $\mathrm{O}$ meu avô gostava de tocar violão

\footnotetext{
2 Com o propósito de apontar respostas e indicar alternativas para possíveis estratégias das políticas públicas afirmativas, visando inserção da população negra nas instituições universitárias, principalmente, as consideradas de tradição e prestígio na sociedade brasileira, existe na UFBA o Programa "A Cor da Bahia" desde 1997, coordenado pela Prof. ${ }^{a}$ Dr. ${ }^{a}$ Delcele Mascarenhas Queiroz. Assim sendo, a UFBA tornou-se em 1998, a primeira instituição universitária do país a dispor de informações que permitem conhecer a cor dos que nela ingressam, assim como dos que nela não conseguem ingressar. Maiores detalhes, em Queiroz (2002).
} 
e a minha avó de sambar e frequentar as festas de largo e procissões. Naquela época, já me emocionava a percorrer o bairro do Uruguai, para ver os altares de Santo Antônio, criativamente, ornados com papel crepom e laminados, de comer o Carurude Cosme e Damião na bacia sobre uma toalha branca, dividida para 07 crianças que ficavam todas sentadas no chão e com os adultos em suas voltas, cantando para estes santos gêmeos.

Era bom sentir os cheiros das comidas e dos incensos bastante peculiares durante estes festejos. Entre as lembranças de minha infância e da minha juventude, o carnaval ocupa um lugar privilegiado na minha história de vida. Recordo-me da minha primeira fantasia de baiana, feita de tecido de cetim com rendas, um turbante acompanhado de uma cestinha cheia de frutas tropicais de massa plástica, das máscaras feitas com tecidos e espumas, dos lança-perfumes adquiridos clandestinamente no porto e que nos perfumava.

Como estudiosa dessas práticas na cidade de Salvador, Estado da Bahia, posso falar com valor de pertencimento aos processos de ações sociopolíticas e culturais (criações artísticas, formações profissionais, construções de identidades), com os quais estes blocos desenvolvem nos seus bairros de origem: Ilê Aiyê, no Curuzu, Olodum, no Pelourinho, Malê Debalê em Itapuã e o Bankoma em Portão. Na perspectiva "desde dentro" eu posso afirmar que as ações desses blocos afro antecedem a Lei 10.639/20037, modificada para a Lei 11.645/2008.

Conheci o bloco afro Ilê Aiyê enquanto aluna do curso de Licenciatura e dançarina do Grupo de Dança Contemporânea - G.D.C., da Escola de Dança da Universidade Federal da Bahia - UFBA, nos períodos de 1975 a 1978, em uma das reuniões do movimento negro que ocorriam no Instituto Cultural Brasil Alemanha - ICBA. Nesta época, faziam parte também do G.D.C., os dançarinos e fundadores do bloco afro Ilê Aiyê: Macalé e Ana Meire, unidos na militância social e também nos eventos coordenados pelo Núcleo Cultural Afro-Brasileiro ${ }^{3}$, mesma época em que surgem para mim outros ensinamentos coreográficos, musicais, teatrais de base afro- 
brasileira. Sempre participo de atividades culturais no Ilê Aiyê, nos concursos de escolhas das suas Deusas do Ébano e na Escola Mãe Hilda como arte-educadora aplicando a técnica de colagem, contribuindo para o entendimento e a importância da Arte na formação psicossocial daqueles estudantes.

Em 2001, eu sou convidada pela Coordenadora geral da Escola Criativa do Olodum, Sra. Simone Magalhães, para atuar na coordenação pedagógica assim como também ser facilitadora nesta parceria do Olodum com a Secretaria Municipal de Educação e Cultura. Já em 2006, eu atuei como apresentadora na escolha do rei e rainha negros Malê no bloco afro Malê Debalê e de 2006 a 2008 fui professora de técnica de dança de matriz africana e coreógrafa do bloco afro Bankoma.

Danço e canto nessas associações carnavalescas baianas organizadas por negros (as), nos chamados "blocos afro"". Sou sujeito encarnando nessas invenções e recepções destas obras. Os ritmos das suas baterias e das suas coreografias enriquecidas e acrescidas pelos cabelos trançados, ouriçados e/ou em dreadlocks, num jogo de cores, de colares e fantasias, que durante os seus desfiles do carnaval, passam-me a sensação de serem uma grande montanha e nós, os (as) foliões (ãs), um rio correndo mansinho na sua base.

Sou dois sujeitos num só: sou artista e pesquisadora que olha, envolve-se e tenta se distanciar destes lugares que são as "casas oníricas" e " raízes" (BACHELARD,1991) de muitos sujeitos, que acolhem, protegem e mostram horizontes. Estes blocos abrilhantam esta cidade barroca com suas canções e danças, fazendo do carnaval da cidade de Salvador uma África "reinventada" (Risério, 1981), rizomática e mítica.

$\mathrm{O}$ artista capta as realidades do mundo, através da sua capacidade de observação, análise e imaginação. A partir das suas referências pessoais,

\footnotetext{
${ }^{3}$ Este grupo, na década de 1970, antecedeu o Movimento Negro Unificado, tendo como fundadores e lideranças o Sociólogo Manoel de Almeida e Roberto Santos.

${ }^{4}$ A denominação bloco afro foi dada pela Bahiatursa - empresa oficial de turismo da Bahia. Essa institucionalização teve, segundo Risério, "o objetivo de domesticar preventivamente o fenômeno afro-carnavalesco, a partir de sua regulamentação" (Risério, 1981, p. 121-124). Com essa inserção dos blocos africano-brasileiros na estrutura oficial do carnaval, continua Risério, "A Bahia conseguiu não só disciplinar o fenômeno carnavalesco, como, além disso, logrou estabelecer um vínculo, ou mais precisamente, forçou os blocos afro a estabelecer um vínculo com ela".
} 
condições socioculturais e de todas as impregnações que o cercam, tornandose visualmente contempláveis, graças às combinações dos movimentos corporais, partituras musicais, canções, figurinos entre outro. Estes blocos afro através das práticas espetaculares nos apresentam vários elementos dos valores civilizatórios afro brasileiros que são: Circularidade, religiosidade, oralidade, corporeidade, energia vital (axé), ludicidade, musicalidade, memória, cooperativismo/comunitarismo e ancestralidade.

$\mathrm{O}$ continente africano enriqueceu e ainda enriquece o nosso país, materialmente e religiosamente. Nesse último aspecto, ele se faz presente em núcleos civilizatórios: as comunidades - os terreiros de Candomblé, as Irmandades religiosas, os grupos de afoxés, os grupos artísticos e sociopolíticos que se constituem em uma das faces mais conhecidas e difundidas da Bahia como também temos os blocos afro, cujos temas para os seus desfiles carnavalescos na maioria das vezes estão relacionados à esse continente.

Através dos coloridos das suas fantasias ou figurinos, nos trançados dos cabelos, nos ritmos musicais do samba Ijexá e do samba reggae, nas suas coreografias, nos seus colares de miçangas, de sementes e de búzios, nos adereços de mãos e de cabeças e nas maquiagens em tons dourados e marrom, consideradas e vistas como heranças africanas - uma África reinventada.

Através das canções dos blocos afro, as pessoas vão pedindo proteções aos ancestrais, elevando a autoestima, afirmação da negritude, enriquecidas pelos sons dos seus tambores, dos timbales, das guitarras, dos pandeiros, entre outros instrumentos, como mostra o compositor Luciano Gomes, na música Faraó5:

Faraó Divindade do Egito

Deuses, divindade infinita do universo

Predominante esquema mitológico

A ênfase do espírito original, Shu

Formará no Éden um ovo cósmico

A Emersão

Nem Osíris sabe como aconteceu

A Emersão

\footnotetext{
${ }^{5}$ Composição musical do ano de 1987, do bloco afro-baiano Olodum, primeiro samba-reggae gravado no Brasil.
} 
Nem Osíris sabe como aconteceu

A Ordem ou submissão do olho seu

Transformou-se na verdadeira humanidade

Epopéia

Do código de Gerbi

E Nut gerou as estrelas

Osíris proclamou matrimônio com Ísis

E o mau Set, irado, o assassinou e impera

Hórus levando avante a vingança do pai

Derrotando o império do mau Set

É o grito da vitória que nos satisfaz

Cadê?

Tutancâmon

Ei, Gizé

Akhaenaton

Ei, Gizé

Tutancâmon

Ei, Gizé

Akhaenaton

Eu falei Faraó

Ê, Faraó

É, eu clamo Olodum Pelourinho

E, Faraó

É Pirâmide, a base do Egito

Ê, Faraó

É, eu clamo Olodum Pelourinho

E, Faraó

É que mara, mara, mara maravilha, ê!

Egito, Egito, ê! Faraó, ó, ó, ó!

Pelourinho

Uma pequena comunidade

Que porém Olodum unira

Em laço de confraternidade

Despertai-vos para a cultura Egípcia no Brasil

Em vez de cabelos trançados

Veremos turbantes de Tutancâmon

E nas cabeças, enchem-se de liberdade

O povo negro pede igualdade. Deixando de lado as separações.

Essa canção bastante conhecida possibilita maravilhosas performances quando executada. Para Zeca Ligiéro "o estudo da performance aplicado ao estudo das tradições cênicas dentro e fora do palco, no Brasil, depara-se primeiramente com a questão do corpo expressivo"(2011, p. 14). O surgimento dos blocos afro contribuiu para o empoderamento da população negra, visando que elas e eles busquem formas de como tratar e arrumar os seus cabelos, como também para a afirmação do corpo negro de seios fartos, nádega avantajada e nariz e pés achatados. Além disso, estes blocos estimulam a criação de como se vestir, 
criando um estilo próprio, tanto na indumentária do cotidiano quanto no carnaval.

Tanto no bloco afro Bankoma quanto nos outros blocos, os cabelos são reinventados através de trançados com fibras sintéticas da marca Kanekalon $^{6}$. Para estas e estes jovens, o ato de trançar o cabelo é uma questão política, associada à ideia de identidade e de beleza negra, elevando a construção da autoestima, reforçando, assim, as suas identidades étnicoraciais.

Destaque dos cabelos trançados com fibras sintéticas e coloridas, da marca Kanekalon, no carnaval baiano.

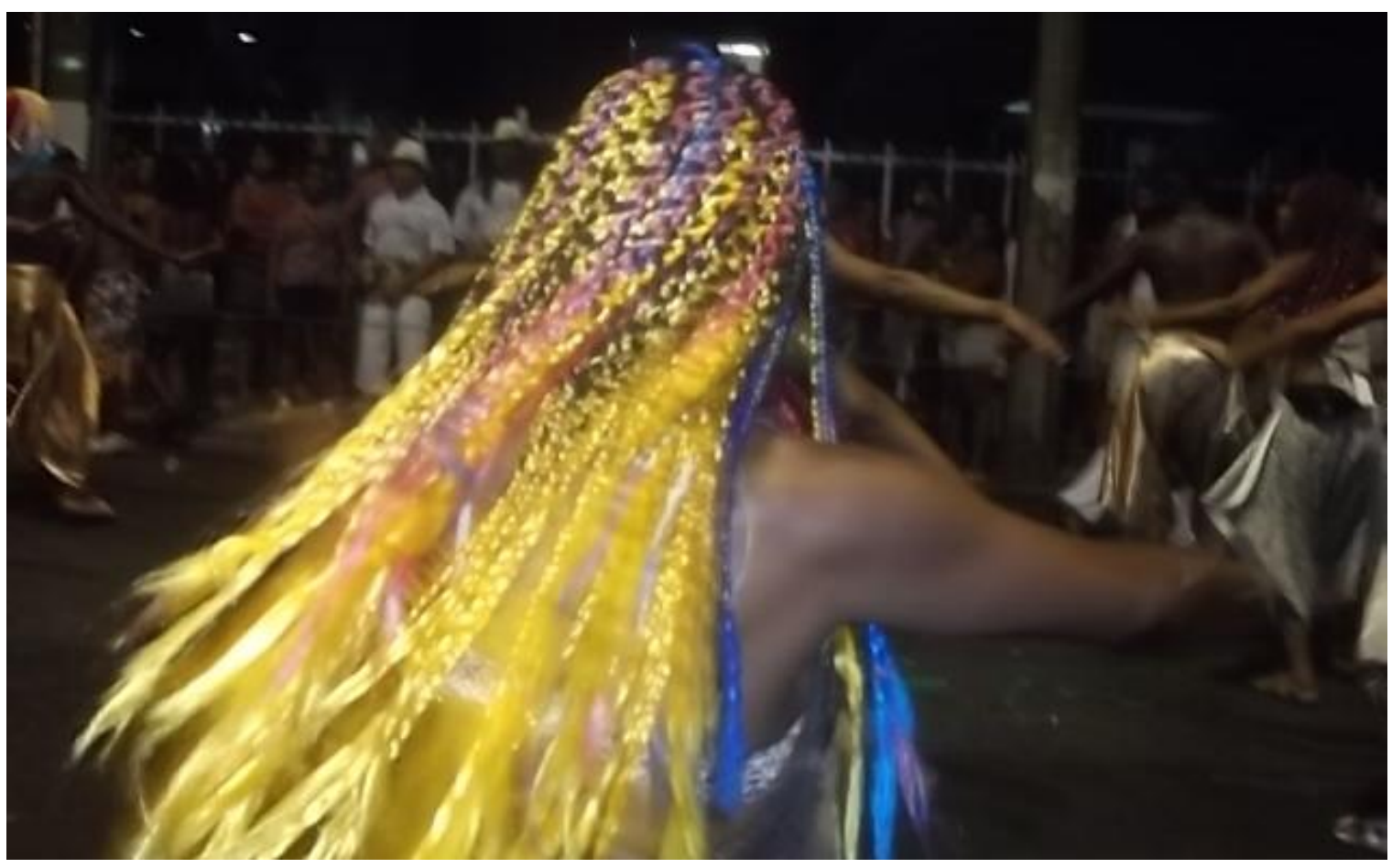

Fonte: Nadir Nóbrega Oliveira, 2012.

O espetacular desses blocos afro transcende os limites dos espaços considerados apenas como culturais, é orientado pela estética negra através de uma identidade mítica fundamentada em aspectos simbólicos da cultura afro-brasileira. As suas atuações foram inspiradas em espaços considerados de resistência negra brasileira os quais podemos citar como exemplo: os

\footnotetext{
${ }^{6}$ Sobre estes materiais bastante utilizados pela população negra, a China é o principal país fabricante destes produtos.
} 
terreiros de Candomblé, as escolas de samba e os blocos de índios. Para Pavis, "o espetacular é uma noção bastante fluida e todas as categorias são definidas a partir da recepção do espectador" (PAVIS, 2005, p.145). O diferencial nesses blocos é que, através dos movimentos do Ijexá e do giká do Candomblé, o espetacular traz bases de memórias culturais africanasbrasileiras articuladas com a contemporaneidade, trazendo para nós um modo de dançar bastante peculiar nesses espetáculos que é o que Suzana Martins chama de get down 7 , - o uso do peso do corpo voltado para o chão com ênfase no nível baixo do espaço, visíveis nas danças de matrizes negroafricanas.

A dança não é o único meio de comunicação humana e tampouco precisa de uma etnia comum para se realizar, podendo ser uma expressão de tempo e espaço, usando o controle dos movimentos, dos gestos para comunicar e expressar emoções. Nos blocos afro, as danças são, geralmente, apresentadas nos palcos e nas suas quadras/sedes, cujo elenco na maioria das vezes está com os pés descalços, porém, durante o carnaval ou em outros eventos nas ruas, os dançarinos e as dançarinas dançam usando alpercatas de couro sintético, sapatilhas ou tênis. As danças apresentadas pelos blocos afro fazem parte do que é convencionado como dança afro-brasileira, com alguns elementos técnicos corporais $^{8}$, que são:

1. Pés planos em contato direto com o chão e flexionados, e pernas semiflexionadas em posições paralelas;

2. Pés dobrados e deslizando na meia ponta;

3. Braços semiflexionados, balançando para frente e para trás e elevando-se de maneira alternada;

4. Movimentos executados, geralmente, obedecendo aos ritmos estabelecidos pelos blocos: samba Ijexá, Aguéré de Òxòssi, samba reggae, entre outros;

\footnotetext{
${ }^{7}$ É o uso do peso do corpo voltado para o chão com ênfase no nível baixo do espaço. Maiores detalhes sobre esta temática ver MARTINS, Suzana, em A Dança de Iemanjá Ogunté: sob a perspectiva do corpo. 2008.

8 Sobre estes elementos e aspectos históricos da dança afro-brasileira ver em OLIVEIRA, Nadir, em Dança Afro: Sincretismo de Movimentos, 1991.
} 
5. Coluna vertebral nos planos vertical e sagital (com flexão e extensão para frente e para os lados). podendo ser movimentos requebrados, soltos percutidos em contratempo com as batidas dos pés no chão;

6. Movimentos assimétricos e circulares com paradas (pausas, expandindo o tempo e o espaço contrastando com o ritmo ou pulsação da música);

7. Bacia óssea em movimentos de retroversão, que no senso comum é conhecido como "bacia desencaixada".

É interessante notar que, na discussão sobre a estética negra, esses blocos afro desde as suas fundações apresentam a música imbricada com a dança, com os cabelos, com os figurinos e adereços, materializando as ancestralidades africanas brasileiras. Tal como na África, a dança e a música são a alma dos blocos afro carnavalescos, elas são Inter e Transdisciplinares, são multidimensionais e têm impactado em muitas áreas do conhecimento da humanidade. Acredito, assim, que os pilares fundamentais e estruturais de danças de matrizes negro-africanas, pesquisadas pela coreógrafa norte americana Kariamu Welsh-Asante (1985), são visíveis em coreografias desses blocos afro e também nas danças sagradas do Candomblé, são eles: a polirritmia ou múltiplos metros, o policentrismo e o holismo.

O Corpo pode aplicar diferentes ritmos para diferentes movimentos evoluindo de maneira integral, podendo a cabeça e as mãos executarem movimentos vibratórios e ao mesmo tempo circulares, enquanto a pélvis contrai, dobrando o ritmos e os pés marcando o metro do tempo. O pilar policentrismo pode ser facilmente observado nestes corpos executando o samba Ijexá e o samba reggae, os quais se locomovem no espaço de maneira expandida estimulados pelos toques das percussões. Já a filosofia holística que baseia o terceiro pilar, que tem "como uma das características a conexão entre as partes do corpo que se movimentam interagindo entre si" (MARTINS, 2008, p. 120). Estas ações são coordenações motoras transmitidas, oralmente e, aparentemente fáceis de execução, porém, como 
um "ser de dentro" destes blocos afro, vejo que estas coordenações motoras exigem determinadas habilidades corporais, pois a polirritmia, o policentrismo e o sentido holístico são atividades de forma sutil.

Aproveito aqui para apresentar alguns registros fotográficos de algumas danças por mim criadas com as minhas ex-alunas, como resultado de uma oficina de Técnica de Dança Afro, por mim ministrada no Terreiro São Jorge da Goméia, no bairro de Portão, séde do bloco afro Bankoma, no qual apliquei os pilares fundamentais e estruturais de danças de matrizes negroafricanas de Kariamu Welsh-Asante ${ }^{9}$ e a dança senegalesa Sabah. Nas fotografias é possível ver a interligação e a inter-relação com o ritmo, a música, os gestos, o figurino, os adereços e o simbolismo das cores, configurando assim um caráter espetacular.

Alunas da oficina de Técnica de Dança Afro, durante as suas performances trajando as fantasias do bloco afro Bankoma: Géssica Catarina, Daniela e Liane, demonstrando o nível médio, os movimentos dos braços apontam para o chão.

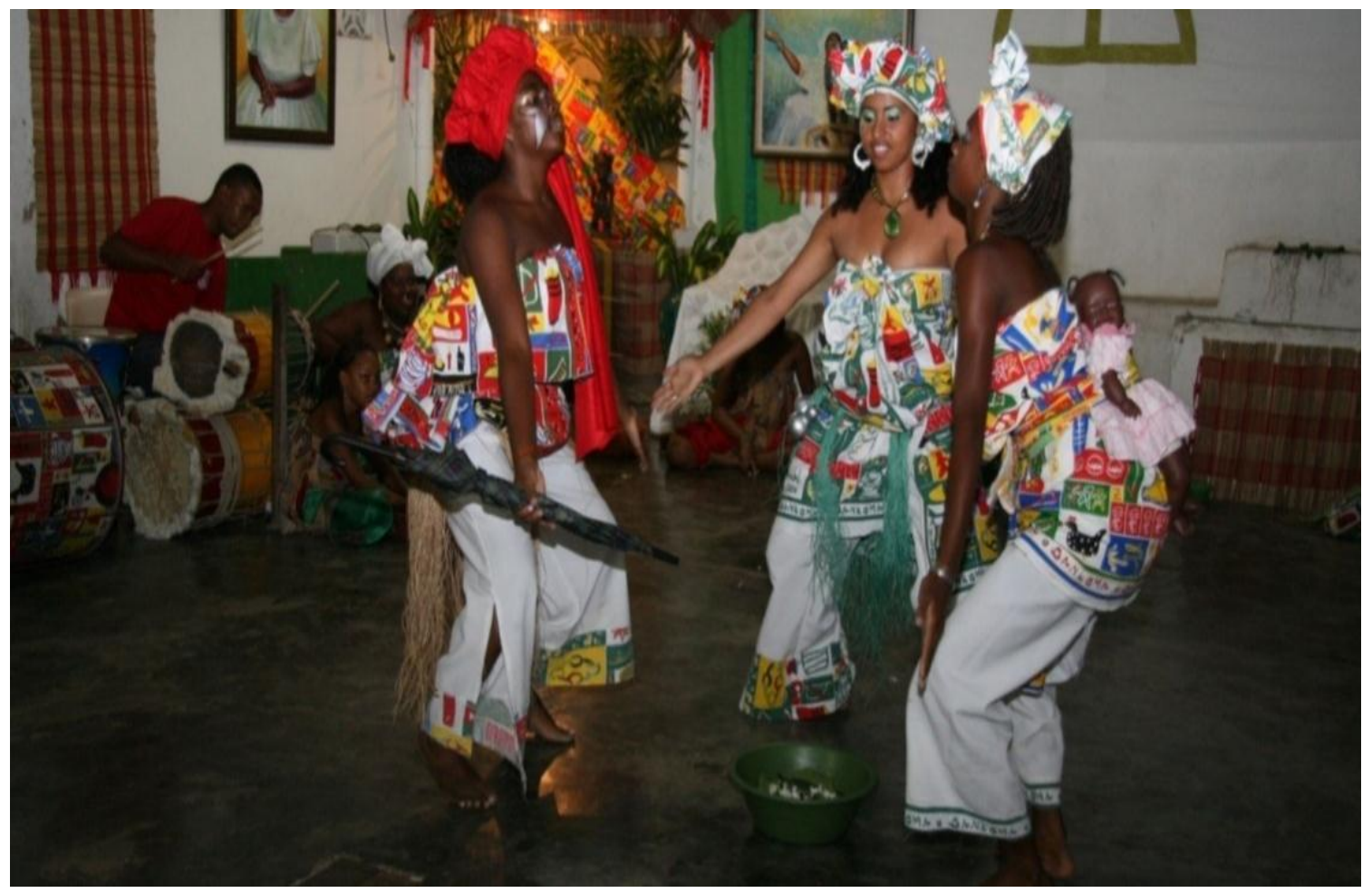

Fonte: Nadir Nóbrega Oliveira, 2008.

\footnotetext{
${ }^{9}$ Kariamu Welsh-Asante criadora da técnica de dança africana Umfundalai.
} 
Os movimentos para o nível médio, podem ser vistos na fotografia acima e dançarinas do bloco afro Bankoma: Géssica Catarina Neves, Daniela Queiroz e Liane dos Santos, numa composição coreográfica, em que elas utilizam objetos do seu cotidiano, relacionados com o tema da aula e com a suas personagens, sendo: uma boneca negra, uma sombrinha e uma bacia com água e búzios. Ao fundo do barracão, pode se ver um altar, junto dele o lugar onde ficam os atabaques. Já no lado esquerdo, está o músico percussionista, Cláudio, os instrumentos percussivos e, na parede de trás, está o quadro de Mãe Mirinha e a pintura de um Ofá, símbolo da divindade Òxòssi.

Uma das minhas ex-alunas, Géssica, exemplifica esse corpo, ilustrando a memória épica e a sua história. Assim, ela se expressa poeticamente:

O meu objeto é uma sombrinha que passa a ser um cajado, porque esse cajado é de Exu e os meus movimentos estão relacionados a ele. A sombrinha no começo do espetáculo vai aberta até a minha colega de dança que a busca como se fosse um escravo levando a madame. (Géssica Catarina, 2008)

Dançarina Aline Santos, tendo como inspiração a orixá Iansã, divindade ancestral africana, em nível médio, enfatiza também o verbo "segurar", com uma colher de pau, na sede do bloco afro Bankoma.

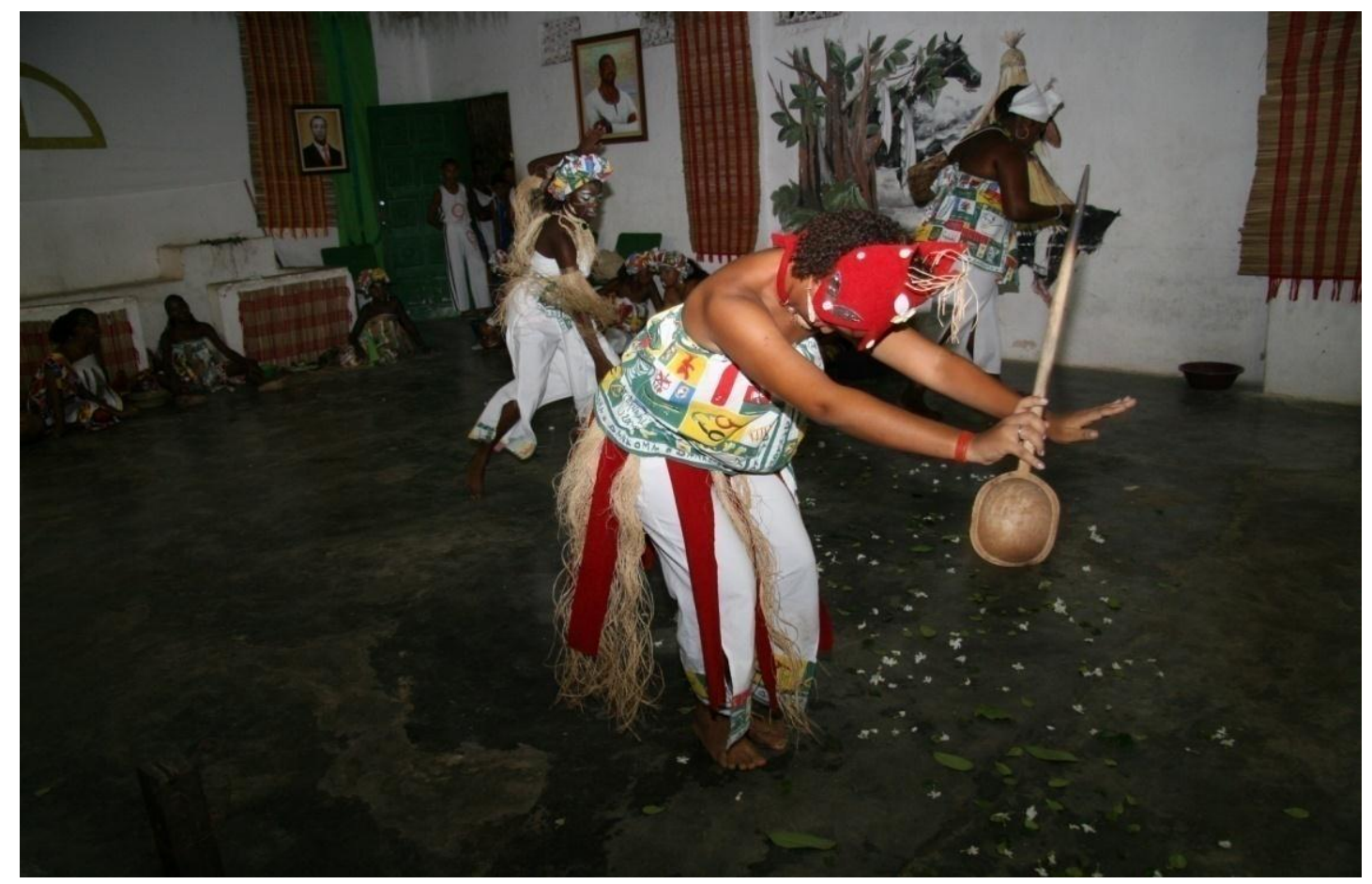

Fonte: Nadir Nóbrega Oliveira, 2008. 
Todas as fotos das composições coreográficas aqui apresentadas enfatizam os pilares fundamentais e estruturais de danças de matrizes negro-africanas apontados por Welsh-Asante, sempre relacionados com as práticas cotidianas civis e religiosas da comunidade do bloco afro Bankoma, possibilitando análises dos aspectos poéticos qualitativos. Em uma das sequências de movimentos em locomoção nestes blocos carnavalescos, os braços semiflexionados que se elevam de maneira revezada, enquanto uma perna é flexionada e elevada em oposto ao braço, com o tronco inclinado para frente e a cabeça virando para um lado e para o outro.

Aline Santos, dançando no nível baixo, em relação ao Aiyê (chão). Ela está segurando uma colher de pau, com a cabeça inclinada para baixo, apoiando-se nos cotovelos e parte inferior do corpo.

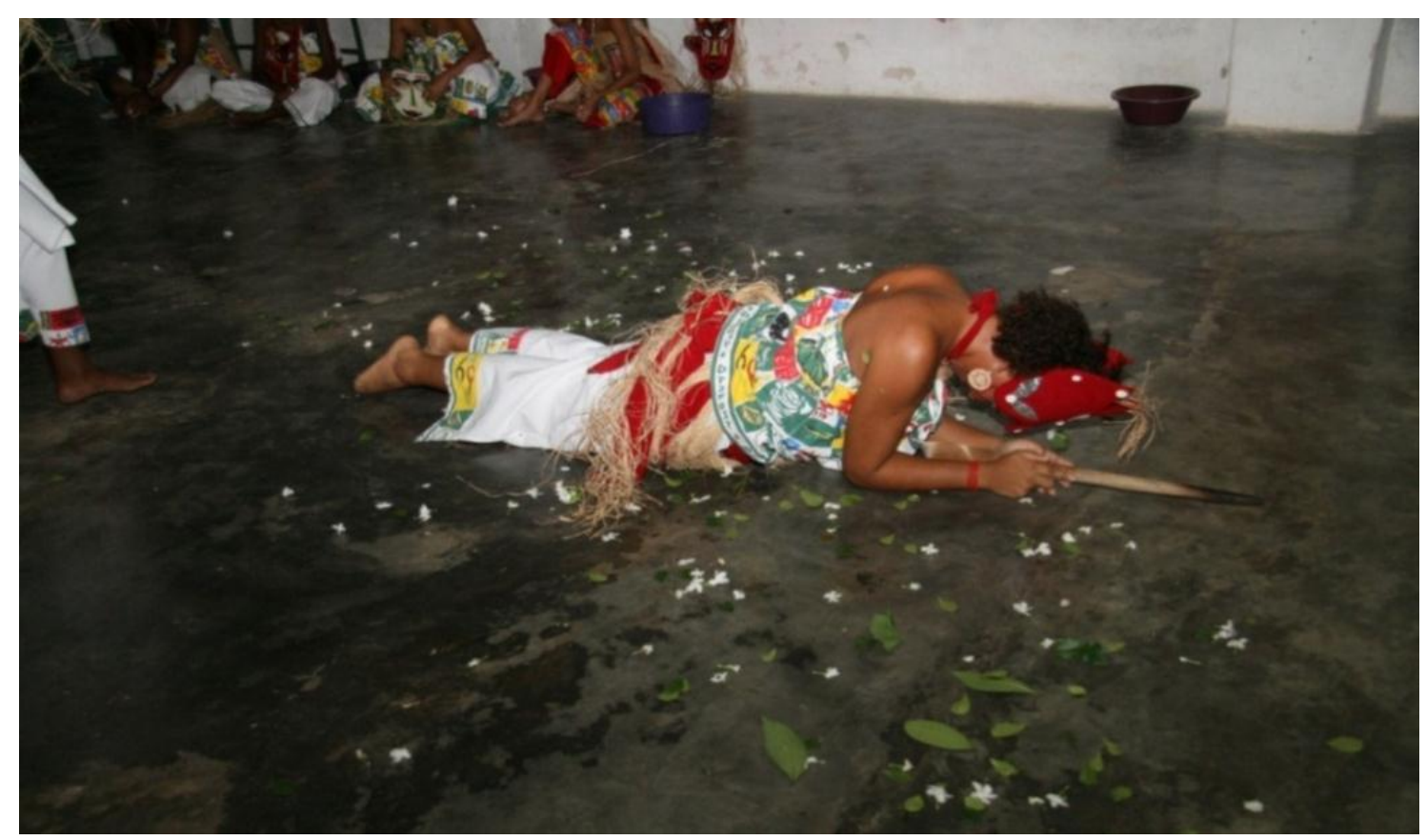

Fonte: Nadir Nóbrega Oliveira, 2008.

Concluo que o carnaval é o tempo especial para a espetacularidade das ações, para o envolvimento com a brincadeira e com a virtude, enfim, esta festa possui a sua magia cósmica estimulada e "ocupada pelos valores da riquíssima tradição civilizatória e cultural afro-brasileira” (Luz, N., 2003, p. 102) dos blocos afro ressaltando essas de sociabilidade dessa presença africana nestas criações de uma estética negra. Mesmo o carnaval sendo a 
vitrine, na qual os blocos afro buscam também outros patrocinadores e foliões, a sensação de alegria embalada pelo samba, este ritmo amalgamado com a dança e que se tornou gênero musical, instituindo a nacionalidade brasileira.

São corpos que vibram, oscilam, crescem, inter-relacionam-se, transformam-se e decompõem-se como a terra, as plantas, o ar e o mar. Corpos captadores, apreendedores, transformadores, criadores de uma determinada estética. $\mathrm{Na}$ minha análise sobre esses corpos negros dos blocos afro, chamo-os de "corpos sujeitos da nossa história". Prefiro enfatizar o lado positivo desses blocos com a frase escrita pela poetisa Rita Mota na entrada da Senzala do Barro Preto (sede do bloco afro Ilê Aiyê) que diz: "nosso sonho almejado já deu certo, eu vi palha com barro virar concreto”.

$$
* * *
$$

\section{REFERÊNCIAS}

BACHELARD, Gaston. A terra e os devaneios do repouso. Tradução Paulo Neves da Silva. São Paulo: Martins Fontes, 1991.

LIGIÉRO, Zeca. Corpo a corpo: estudos das performances brasileiras. Rio de Janeiro: Garamond, 2011.

LUZ, C. P. Narcimária. Abébé: a criação de novos valores na Educação.Salvador: SECNEB, 2003.

MARTINS, Suzana. A dança de Yemanjá Ogunté sob a perspectiva estética do corpo. Salvador: EGBA, 2008.

OLIVEIRA, Nadir Nóbrega. Agô Alafiju, Odara! A presença de Clyde Morgan na Escola de Dança da Universidade Federal da Bahia, de 1971 a 1978. Salvador: Fundação Pedro Calmon, 2007.

Dança afro-sincretismo de movimentos. Salvador: EDUFBA. 1991. 
PAVIS, Patrice. Dicionário de Teatro. Tradução para a língua portuguesa sob a direção de J. Guinsburg e Maria Lúcia Pereira. São Paulo: Perspectiva, 2005.

QUEIROZ, Delcele Mascarenhas (Coord.). O negro na universidade. Salvador: Novos Toques, 2002.

RISÉRIO, Antonio. Carnaval Ijexá: notas sobre afoxés e blocos do novo carnaval afrobaiano. Salvador: Corrupio, 1981.

WELSH-ASANTE, Kariamu. African Dance. USA: Chelsea House Publishers. 2004.

Recebido em março de 2020.

Aprovado em abril de 2020.

Publicado em junho de 2020. 